\title{
Development of ICT competence among students when teaching inverse problems for differential equations with the use of computer technology
}

\author{
Viktor S. Kornilov \\ Moscow City University \\ 29 Sheremetyevskaya St., Moscow, 127521, Russian Federation
}

Problem and goal. The great need to apply the theory of inverse problems for differential equations (IP) in the research of applied problems is explained by the fact that it is possible to effectively study hard-to-reach or inaccessible objects and processes, to identify, for example, the location of objects, determine their shape, etc. In addition, it is possible to identify causeand-effect relationships of processes and phenomena (see, for example, $[5 ; 6 ; 8 ; 11 ; 14 ; 17 ; 19]$ ). It became possible, in many respects, thanks to modern computer technologies which allow to investigate various mathematical models of inverse problems, realize modern computational algorithms of the numerical solution of inverse problems for differential equations, carry out three-dimensional visualization of their decisions and control of accuracy of calculations.

This circumstance explains the widespread introduction of modern computer technologies in the process of teaching students of IP educational institutions of physics and mathematics (see, for example, $[2 ; 5 ; 6 ; 8 ; 10-14 ; 17 ; 19 ; 20]$ ). In the process of teaching, goals are set to ensure that students form a system of fundamental knowledge in the field of theory and practice of inverse problems, applied and computational mathematics, acquire the skills to choose and apply computer technology to find solutions to inverse problems, develop their ICT competence.

Methodology. The development of ICT competence among students of universities of physical and mathematical areas of training, as a result of learning IP, is ensured by how successfully the conditions will be implemented in practice, including: 1) involvement of specialists in the field of inverse problems for differential equations with experience in the use of computer technology in the study of inverse problems; 2) conducting lectures and practical classes using multimedia and computer technologies; 3) implementation of didactic principles of teaching inverse problems for differential equations using computer technologies; 4) attraction of students to performance of semester tasks, course and final qualifying works on inverse problems for differential equations with use of computer technologies.

Results. In practical classes, students acquire the skills to apply modern computer technology in the study of IP. Students gain experience in analyzing new information about the studied physical processes and phenomena using computer technology. Students form knowledge about the role of computer technology in mobile research of mathematical models of inverse problems for differential equations, demonstrating ICT competence.

(C) Kornilov V.S., 2019

This work is licensed under a Creative Commons Attribution 4.0 International License https://creativecommons.org/licenses/by/4.0/ 
Conclusion. Developed in the process of teaching inverse problems for differential equations using computer technologies, ICT competence will obviously allow students in their future professional activities to effectively apply a variety of computer technologies in the study of mathematical models of inverse problems.

Key words: learning inverse problems for differential equations; informatization of learning; ICT competence; computer technology; student

Problem statement. Computer technologies are widely used in modern applied mathematics, the methods of which allow to study complex processes and phenomena of different nature, and to use the acquired knowledge in practical activities. The use of computer modeling as one of the modern information technologies in the development of the theory and practice of mathematical models research currently plays an important role. It is possible to identify certain properties of the mathematical model; make appropriate conclusions about the properties of the studied processes and phenomena, which can then be justified, and in the future can serve as a foundation for theoretical research. There is an opportunity to accumulate the results obtained in the study of some applied problems, and then effectively apply them to solving problems in different areas of economics, industry, agriculture, natural sciences, humanities and social sciences. Computer simulation is indispensable in cases where a physical experiment is impossible because it is either forbidden, dangerous, or impracticable, or the object under study exists in a single instance.

In this regard, the curricula of higher educational institutions contain such disciplines as "Computer modeling", "Information technology in mathematics", "Informatization of education" and other disciplines. The development of such disciplines allows students to understand the methodology of modeling in the knowledge of the world; form students understanding of the role of computer technology in solving applied problems; provide students with ample opportunities for understanding the connection of applied mathematics with natural, humanitarian and social sciences (see, for example, $[1 ; 2 ; 8 ; 10 ; 14 ; 20]$ ).

Currently, the university system of training specialists in applied mathematics is experiencing a contradiction, on the one hand, between the need for students to develop a large amount of fundamental scientific knowledge, allowing them after graduation, working in scientific institutions, to successfully solve a variety of complex mathematical problems in the implementation of applied research in practice and, on the other hand, the limited time allotted for the development of such fundamental scientific knowledge.

This has much to do with teaching inverse problems for differential equations, which constitute one of the directions of modern applied mathematics. One of the ways to overcome this contradiction is the use of modern multimedia and computer technologies in the process of teaching students inverse problems for differential equations. The use, together with the fundamental principles of classical education, of modern multimedia and computer technologies allows us to qualitatively change the approaches and methods of teaching inverse problems for differential equations. 
The teacher is given the opportunity to use a demonstration method of teaching at lectures: on interactive whiteboards, it is possible to quickly demonstrate analytical and approximate solutions of applied mathematical problems, two-dimensional and three-dimensional graphs of their solutions, tables, drawings, etc.

The use of multimedia and computer technologies allows to implement various forms and methods of teaching inverse problems, in which the cognitive activity of students is activated. Among the forms of teaching students inverse problems for differential equations, laboratory classes are used as a type of training session. The inclusion in the learning process, in addition to lectures and seminars, such a form of training organization as laboratory classes with the use of modern computer technologies allows to achieve a high level of knowledge assimilation, mastering the necessary applied mathematical apparatus by activating the educational and cognitive activity of students and makes it advisable to use this form of training organization.

Methods of research. Under ICT competence, specialists understand a complex concept that characterizes the way of human life in the modern information society and includes targeted effective use of information and telecommunication technologies in their professional and daily activities. The concept of ICT competence is used by many specialists in the works devoted to informatization of education. The methodical aspects of ICT competence development are devoted to the works of such authors as T.A. Boronenko, N.V. Buzhinskaya, V.F. Burmakina, V.V. Grinshkun, E.V. Danilchuk, S.A. Zaitseva, V.R. Imakaev, S.S. Kartseva, T.G. Kiseleva, A.A. Kuznetsov, M.P. Lapchik, I.Yu. Lepeshinsky, O.N. Novikova, V.N. Podkovyrova, M.I. Ragulin, L.B. Senkevich, S.R. Udalov, S.A. Fadeev, G.A. Fedorova, V.S. Fedotova, E.K. Henner, E.V. Chernobay and others (see, for example, $[3 ; 4 ; 7 ; 9 ; 15-18])$.

The content of teaching inverse problems for differential equations includes conceptual and mathematical apparatus from various mathematical disciplines, methods of mathematical modeling, research methods of mathematical models themselves, qualitative analysis of solutions, etc. Inverse problems for differential equations are usually nonlinear mathematical problems, since usually unknown coefficients, the right parts of the differential equation and the solution of the differential equation itself are determined simultaneously. In most cases, the solution of the corresponding direct problem can be represented only in the form of an integral equation or an integrodifferential equation. It is worth noting that in some cases there are statements of inverse problems, the solutions of which, despite their nonlinearity, can be obtained in the form of formulas.

The scheme of investigation of inverse problems for differential equations includes two stages. At the first stage, the solution of the direct problem is constructed and its properties are investigated under the assumption that the desired functions are known and belong to specific functional spaces. In the second stage, the inverse problem itself is investigated. Using the constructed equation of the direct problem, the corresponding system of equations of the inverse problem is consistently constructed. Then we prove theorems on existence, uniqueness and conditional stability of an inverse problem, where the matching conditions data of the inverse problem. 
The purpose of the study of the inverse problem for differential equations is a constructive construction of its solution. In the process of studying the inverse problem, mathematical difficulties are overcome, such as the construction of a solution of a direct problem, which has a complex form; analysis of the properties of the constructed solution of a direct problem; differentiation and integration of cumbersome mathematical expressions, including integral equations, the use of approximate methods of solution, etc. It takes a lot of time, there is a possibility to make a mistake in the calculations, which can lead to incorrect results and erroneous conclusions. Students face similar difficulties in solving inverse problems for differential equations.

Currently, computer mathematics systems such as Maple, Mathematica, Matlab, MathCad and others are used in the educational process of higher education institutions. One of the advantages of computer mathematics systems is that it is possible to study complex mathematical problems. The teacher is given the opportunity to use a visual demonstration method of teaching: on the computer screen, you can quickly demonstrate analytical and approximate solutions of mathematical problems, two-dimensional and three-dimensional graphs of their solutions, tables, drawings, etc. Students get rid of routine work associated with cumbersome mathematical calculations and transformations; gain confidence in symbolic calculations and practical skills of mathematical reasoning and analysis of the results; get the opportunity to independently and quickly solve a variety of mathematical problems.

Students without the teacher in the consistent implementation of the relevant commands can quickly find analytic and approximate solutions of direct problems for some ordinary differential equations and partial differential equations, which will later be used to select additional information about the solution of the direct problem, building a system of integral equations of the inverse problem. Students can apply methods for solving differential or integral equations, build graphs of complex functions and surfaces, with which, for example, solutions of direct and inverse problems are evaluated, which greatly facilitates their analysis. Students can find solutions to various integral and integro-differential equations; thus get rid of complex routine mathematical transformations; get rid of the fear of making a mistake in the process of solving the inverse problem, etc.

The use of computer mathematics systems for the implementation of computational algorithms for solving inverse problems for differential equations allows students to visualize the computational algorithm for solving the corresponding inverse problem, analyze it, quickly obtain new results of numerical calculations when data changes and visualize them graphically. As a result of the use of computer technology, students gain experience and skills to explore mobile applied mathematical problems, which allows to assess and identify the possibilities of computer technology in solving a variety of mathematical problems, to develop ICT competence.

Results and discussion. The use of modern multimedia and computer technologies in lectures and practical classes in teaching students of higher educational institutions of physical and mathematical areas of training universities inverse problems for differential equations contributes to the implementation of didactic 
principles of training. Laboratory classes, using computer technology, as an organizational form of educational activity in teaching inverse problems have their own specifics, which involves the development of appropriate guidelines. Conducting such laboratory classes with a high mathematical level, complex conceptual apparatus, mathematical methods of research and the complexity of research, methodically justified.

Such laboratory classes integrate theoretical and methodological knowledge, practical skills and abilities of students in a single process of educational and research activities. With proper organization of laboratory work, students act as researchers of inverse problems for differential equations.

Conclusion. The presence of fundamental knowledge on inverse problems for differential equations, skills and abilities to independently apply computer technology in the study of inverse problems, allows them to develop professional competencies, including ICT competencies. ICT competencies help such students in their future professional activity in the field of applied mathematics to successfully develop not only the methods of world science, but also to solve important problems in industry, economy, agriculture and many other spheres of human activity. It is obvious that a student with ICT competence, in his future professional activity as a mathematician-researcher is able to independently with the use of modern information technologies to successfully solve complex applied problems from different subject areas.

\section{References}

[1] Belenkova I.V. Metodika ispol'zovanija matematicheskih paketov v professional'noj podgotovke studentov vuza [Method of using mathematical packages in professional training of university students]: dissertation of the candidate of pedagogical sciences. Ekaterinburg, 2004. 170 p.

[2] Bidaibekov E.S., Kornilov V.S., Kamalova G.B. Obuchenie budushhih uchitelej matematiki i informatiki obratnym zadacham dlja differencial'nyh uravnenij [The training of future teachers of mathematics and informatics inverse problems for differential equations]. Vestnik Moskovskogo gorodskogo pedagogicheskogo universiteta. Seriya: Informatika i informatizacija obrazovanija [Bulletin of the Moscow City Pedagogical University. Series: Informatics and Informatization of Education]. 2014. No. 3(29). Pp. 57-69.

[3] Buzhinskaya N.V. Metodika ocenki urovnja IKT-kompetentnosti studentov pedagogicheskih vuzov [Methodology for assessing the level of ICT competence of students of pedagogical universities]. Vestnik Brjanskogo gosudarstvennogo universiteta [Bulletin of the Bryansk State University]. 2016. No. 1(27). Pp. 319-324.

[4] Boronenko T.A., Fedotova V.S. Formirovanie IKT-kompetentnosti nauchno-pedagogicheskih kadrov v trehurovnevoj sisteme vysshego obrazovanija [Formation of ICT competence of scientific and pedagogical personnel in the three-level system of higher education]. Obrazovanie i nauka [Education and science]. 2016. No. 1. Pp. 95-106.

[5] Vatulyan A.O., Belyak O.A., Sukhov D.Yu., Yavruyan O.V. Obratnye i nekorrektnye zadachi [Inverse and ill-posed problems]: textbook. Rostov-on-Don: Southern Federal University Publ., 2011. 232 p. 
[6] Denisov A.M. Vvedenie v teoriju obratnyh zadach [Introduction to the theory of inverse problems]: textbook. Moscow: Izd-vo Moskovskogo universiteta, 1994. 207 p.

[7] Efimova T.N. Formirovanie informacionno-kommunikativnoj kompetentnosti kak neobhodimoe uslovie jeffektivnosti professional'noj dejatel'nosti budushhego specialist [Formation of information and communication competence as a necessary condition for the effectiveness of professional activity of the future specialist]. http://migha.ru/formirovanieinformacionno-kommunikativnoj-kompetentnosti.html (accessed: 31.07.2019).

[8] Kabanikhin S.I. Obratnye i nekorrektnye zadachi [Inverse and ill-posed problems]: a textbook for university students. Novosibirsk: Sibirskoe nauchnoe izdatel'stvo, 2009. $458 \mathrm{p}$.

[9] Kiseleva T.G., Kartseva S.S. Model formirovanija IKT-kompetencii u studentov pedagogicheskih special'nostej [Model of ICT competence formation in students of pedagogical specialties]. Za kachestvennoe obrazovanie [For quality education]: proceedings of III All-Russian forum (with international participation). Saratov: SGMU, 2018. http:// filling-form.ru/other/121775/index.html?page=25 (accessed: 31.07.2019).

[10] Kornilov V.S. Realizacija didakticheskih principov obuchenija pri ispol'zovanii obrazovatel'nyh jelektronnyh resursov v kurse "Obratnye zadachi dlja differencial'nyh uravnenij" [Implementation of didactic principles of teaching using educational electronic resources in the course "Inverse problems for differential equations"]. Vestnik Rossijskogo universiteta druzhby narodov. Seriya: Informatizacija obrazovanija [Bulletin of Peoples' Friendship University of Russia. Series: Informatization in Education]. 2006. No. 1(3). Pp. 40-44.

[11] Kornilov V.S. Obratnye zadachi v soderzhanii obucheniya prikladnoj matematike [Inverse problems in the content of teaching applied mathematics]. Vestnik Rossijskogo universiteta druzhby narodov. Seriya: Informatizacija obrazovanija [Bulletin of Peoples' Friendship University of Russia. Series: Informatization in Education]. 2014. No. 2. Pp. 109-118.

[12] Kornilov V.S. Obuchenie studentov obratnym zadacham dlja differencial'nyh uravnenij kak faktor formirovanija kompetentnosti v oblasti prikladnoj matematiki [Teaching students inverse problems for differential equations as a factor of competence formation in the field of applied mathematics]. Vestnik Rossijskogo universiteta druzhby narodov. Seriya: Informatizacija obrazovanija [Bulletin of Peoples 'Friendship University of Russia. Series: Informatization in Education]. 2015. No. 1. Pp. 63-72.

[13] Kornilov V.S. Realizacija nauchno-obrazovatel'nogo potenciala obuchenija studentov vuzov obratnym zadacham dlja differencial'nyh uravnenij [Realization of scientific and educational potential of training of students of higher education institutions in the inverse problems for the differential equations]. Kazanskij pedagogicheskij zhurnal [Kazan pedagogical journal]. 2016. No. 6. Pp. 55-59.

[14] Kornilov V.S. Teorija i metodika obuchenija obratnym zadacham dlja differencial'nyh uravnenij [Theory and technique of training to the inverse problems for differential equations]: monography. Moscow: OntoPrint Publ., 2017. 500 p.

[15] Kornilov V.S., Karymsakova A.J. Informatizacija obuchenija budushhih uchitelej matematiki linejnoj algebre kak faktor razvitija IKT-kompetentnosti [Informatization of training of future teachers of mathematics in linear algebra as a factor of ICT competence development]. Vestnik Moskovskogo gorodskogo pedagogicheskogo universiteta. Seriya: Informatika i informatizacija obrazovanija [Bulletin of the Moscow City Pedagogical University. Series: Informatics and Informatization of Education]. 2019. No. 3(49). Pp. 69-79.

[16] Nesterova I.A. IKT-kompetentnost [ICT competence]. http://odiplom.ru/lab/ikt-kompetentnost.html (accessed: 31.07.2019). 
[17] Romanov V.G. Obratnye zadachi dlja differencial'nyh uravnenij [Inverse problems for differential equations]: special course for NGU students. Novosibirsk: NGU, 1973. 252 p.

[18] Sabitova N.G. Formirovanie informacionno-kommunikacionnyh kompetencij studentov bakalavriata sredstvami jelektronnyh obrazovatel'nyh tehnologij [Formation of information and communication competences of undergraduate students by means of electronic educational technologies]: dissertation of the candidate of pedagogical sciences. Izhevsk, 2012. $200 \mathrm{p}$.

[19] Yurko V.A. Vvedenie v teoriyu obratnyh spektral'nyh zadach [Introduction to the theory of inverse spectral problems]: textbook. Moscow: Fizmatlit Publ., 2007. 384 p.

[20] Bidaibekov Y.Y., Kornilov V.S., Kamalova G.B., Akimzhan N.Sh. Fundamentalization of knowledge system on applied mathematics in teaching students of inverse problems for differential equations. AIP Conference Proceedings (Antalya, Turkey, November 5-7, 2015). 2015. Vol. 1676. No. 1. https://doi.org/10.1063/1.4930470

\title{
Article history:
}

Received: 15 August 2019

Accepted: 15 September 2019

\section{For citation:}

Kornilov V.S. (2019). Development of ICT competence among students when teaching inverse problems for differential equations with the use of computer technology. RUDN Journal of Informatization in Education, 16(4), 328-337. http://dx.doi.org/10.22363/23128631-2019-16-4-328-337

\section{Bio note:}

Viktor S. Kornilov, doctor of pedagogical sciences, candidate of physical and mathematical sciences, full professor, deputy head of the Department of Informatization of Education of the Moscow City University. Contact information: e-mail: vs_kornilov@mail.ru

Научная статья

\section{Развитие ИКТ-компетентности у студентов при обучении обратным задачам для дифференциальных уравнений с использованием компьютерных технологий}

\author{
В.С. Корнилов \\ Московский городской педагогический университет \\ Российская Федерация, 127521, Москва, ул. Шереметьевская, 29
}

Проблема и цель. Большая потребность применения теории обратных задач для дифференциальных уравнений (О3) в исследованиях прикладных задач объясняется возможностью эффективно изучать труднодоступные или недоступные совсем объекты и процессы, выявлять, например, местоположения объектов, определять их форму и т. д. Кроме того, возможно выявить причинно-следственные связи происходящих процессов и явлений (см., например, $[5 ; 6 ; 8 ; 11 ; 14 ; 17 ; 19])$. Это оказалось доступным во многом 
благодаря современным компьютерным технологиям, которые позволяют исследовать разнообразные математические модели обратных задач, реализуют современные вычислительные алгоритмы численного решения обратных задач для дифференциальных уравнений, осуществляют трехмерную визуализацию их решений и контроль точности вычислений.

Данное обстоятельство объясняет широкое внедрение современных компьютерных технологий в процесс обучения О3 студентов высших учебных заведений физико-математических направлений подготовки (см., например, $[2 ; 5 ; 6 ; 8 ; 10-14 ; 17 ; 19 ; 20])$. В процессе преподавания ставятся цели, направленные на то, чтобы студенты сформировали систему фундаментальных знаний в области теории и практики обратных задач, прикладной и вычислительной математики, приобрели умения и навыки выбирать и применять компьютерные технологии для поиска решений обратных задач, развили свою ИКТ-компетентность.

Методология. Развитие ИКТ-компетентности у студентов вузов физико-математических направлений подготовки в результате обучения О3 обеспечивается тем, насколько успешно будут реализованы на практике условия, среди которых: 1) привлечение специалистов в области обратных задач для дифференциальных уравнений, имеющих опыт применения компьютерных технологий при исследовании обратных задач; 2) проведение лекционных и практических занятий с использованием мультимедийных и компьютерных технологий; 3) реализация дидактических принципов обучения обратным задачам для дифференциальных уравнений с использованием компьютерных технологий; 4) привлечение студентов к выполнению семестровых заданий, курсовых и выпускных квалификационных работ по обратным задачам для дифференциальных уравнений с использованием компьютерных технологий.

Результаты. На практических занятиях студенты приобретают умения и навыки применять современные компьютерные технологии при исследовании О3, а также опыт анализа новой информации об исследуемых физических процессах и явлениях с использованием компьютерных технологий. Студенты формируют знания о роли компьютерных технологий в мобильном исследовании математических моделей О3, демонстрируя ИКТ-компетентность.

Заключение. Развитая в процессе обучения О3 с использованием компьютерных технологий ИКТ-компетентность позволит студентам в своей будущей профессиональной деятельности эффективно применять разнообразные компьютерные технологии при исследовании математических моделей обратных задач.

Ключевые слова: обучение обратным задачам для дифференциальных уравнений; информатизация обучения; ИКТ-компетентность; компьютерные технологии; студент

\section{Список литературы}

[1] Беленкова И.В. Методика использования математических пакетов в профессиональной подготовке студентов вуза: дис. ... канд. пед. наук. Екатеринбург, 2004. 170 с.

[2] Бидайбеков Е.Ы., Корнилов В.С., Камалова Г.Б. Обучение будущих учителей математики и информатики обратным задачам для дифференциальных уравнений // Вестник Московского городского педагогического университета. Серия: Информатика и информатизация образования. 2014. № 3 (29). С. 57-69.

[3] Бужинская Н.B. Методика оценки уровня ИКТ-компетентности студентов педагогических вузов // Вестник Брянского государственного университета. 2016. № 1 (27). C. 319-324. 
[4] Бороненко Т.А., Федотова В.С. Формирование ИКТ-компетентности научно-педагогических кадров в трехуровневой системе высшего образования // Образование и наука. 2016. № 1. С. 95-106.

[5] Ватульян А.О., Беляк О.А., Сухов Д.Ю., Явруян О.В. Обратные и некорректные задачи: учебное пособие. Ростов н/Д: Изд-во Южного федерального университета, 2011. $232 \mathrm{c}$.

[6] Денисов А.М. Введение в теорию обратных задач: учебное пособие. М.: Изд-во Московского университета, 1994. 207 с.

[7] Ефимова Т.Н. Формирование информационно-коммуникативной компетентности как необходимое условие эффективности профессиональной деятельности будущего специалиста. URL: http://migha.ru/formirovanie-informacionno-kommunikativnojkompetentnosti.html (дата обращения: 31.07.2019).

[8] Кабанихин С.И. Обратные и некорректные задачи: учебник для студентов вузов. Новосибирск: Сибирское научное издательство, 2009. 458 с.

[9] Киселева Т.Г., Кариева С.С. Модель формирования ИКТ-компетенции у студентов педагогических специальностей // За качественное образование: материалы III Bceроссийского форума (с международным участием). Саратов: СГMУ, 2018. URL: http://filling-form.ru/other/121775/index.html?page=25 (дата обращения: 31.07.2019).

[10] Корнилов В.С. Реализация дидактических принципов обучения при использовании образовательных электронных ресурсов в курсе «Обратные задачи для дифференциальных уравнений» // Вестник Российского университета дружбы народов. Серия: Информатизация образования. 2006. № 1 (3). С. 40-44.

[11] Корнилов В.С. Обратные задачи в содержании обучения прикладной математике // Вестник Российского университета дружбы народов. Серия: Информатизация образования. 2014. № 2. С. 109-118.

[12] Корнилов В.С. Обучение студентов обратным задачам для дифференциальных уравнений как фактор формирования компетентности в области прикладной математики // Вестник Российского университета дружбы народов. Серия: Информатизация образования. 2015. № 1. С. 63-72.

[13] Корнилов В.С. Реализация научно-образовательного потенциала обучения студентов вузов обратным задачам для дифференциальных уравнений // Казанский педагогический журнал. 2016. № 6. С. 55-59.

[14] Корнилов В.С. Теория и методика обучения обратным задачам для дифференциальных уравнений: монография. М.: ОнтоПринт, 2017. 500 с.

[15] Корнилов В.С., Карымсакова А.Ж. Информатизация обучения будущих учителей математики линейной алгебре как фактор развития ИКТ-компетентности // Вестник Московского городского педагогического университета. Серия: Информатика и информатизация образования. 2019. № 3 (49). С. 69-79.

[16] Нестерова И.А. ИКТ-компетентность. URL: http://odiplom.ru/lab/ikt-kompetentnost. html (дата обращения: 31.07.2019).

[17] Романов В.Г. Обратные задачи для дифференциальных уравнений: спецкурс для студентов НГУ. Новосибирск: НГУ, 1973. 252 с.

[18] Сабитова Н.Г. Формирование информационно-коммуникационных компетенций студентов бакалавриата средствами электронных образовательных технологий: дис. ... канд. пед. наук. Ижевск, 2012. 200 с.

[19] Юрко В.А. Введение в теорию обратных спектральных задач: учебное пособие. М.: Физматлит, 2007. 384 с. 
[20] Bidaibekov Y.Y., Kornilov V.S., Kamalova G.B., Akimzhan N.Sh. Fundamentalization of knowledge system on applied mathematics in teaching students of inverse problems for differential equations // AIP Conference Proceedings (Antalya, Turkey, November 5-7, 2015). 2015. Vol. 1676. No. 1. https://doi.org/10.1063/1.4930470

\section{История статьи:}

Дата поступления в редакцию: 15 августа 2019

Дата принятия к печати: 15 сентября 2019

\section{Для цитирования:}

Kornilov V.S. Development of ICT competence among students when teaching inverse problems for differential equations with the use of computer technology (Развитие ИКТкомпетентности у студентов при обучении обратным задачам для дифференциальных уравнений с использованием компьютерных технологий) // Вестник Российского университета дружбы народов. Серия: Информатизация образования. 2019. Т. 16. № 4. C. 328-337. http://dx.doi.org/10.22363/2312-8631-2019-16-4-328-337

\section{Сведения об авторе:}

Корнилов Виктор Семенович, доктор педагогических наук, кандидат физико-математических наук, профессор, профессор кафедры информатизации образования Московского городского педагогического университета. Контактная информация: e-mail: vs_kornilov@mail.ru 